

\title{
Os evangélicos na política de Rondônia:
}

\section{análise de duas candidaturas na Campanha Eleitoral de 1982}

\author{
Vinicius Rodrigues Dias \\ ORCID: \\ Mestrando no Programa de Pós-Graduação de História da UFPEL; \\ E-mail: viniciusrd2011@hotmail.com
}

Resumo: Neste artigo, faremos uma breve apresentação e discussão acerca do comportamento eleitoral de dois candidatos a deputados estudais na eleição de 1982 no estado de Rondônia. Esperando contribuir nos estudos sobre o tema da entrada de evangélicos na política brasileira.

Palavras chaves: Rondônia, evangélicos e eleição de 1982.

\section{The evangelicals in the politics of Rondônia:}

\section{analysis of two candidacies in the Electoral Campaign of 1982}

\begin{abstract}
In this article, we will make a brief presentation and discussion about the electoral behavior of two candidates for student deputies in the 1982 election in the state of Rondônia. Hoping to contribute in the studies on the subject of the entrance of evangelicals in Brazilian politics.
\end{abstract}

Keywords: Rondônia, evangelicals and the 1982 election. 


\section{Introdução}

O presente texto é resultado da pesquisa monográfica realizada no ano de 2017 , onde fora discorrida sobre o comportamento eleitoral de dois candidatos a deputados estaduais no estado de Rondônia em 1982. Destarte, as discussões presentes neste artigo é parte do último capítulo da pesquisa monografia.

Assim discorreremos neste texto a trajetória de duas candidaturas a deputados estaduais no ano de 1982: Amizael Silva do PDS e de Sadraque Muniz filiado no PMDB. Sendo os mesmos membros da igreja evangélica Assembleia de Deus, desde a infância.

Elegemos como objetivo deste artigo demostrar que as candidaturas de Amizael Silva e Sadraque Muniz, foram frutos dos interesses das suas respectivas agremiações partidárias às quais eram filiados e, não de projetos de poder da igreja evangélica a qual faziam parte.

Também pretende-se confirmar que os discursos de campanha dos candidatos em questão, ao serem proferidos ao eleitorado rondoniense eram semelhantes aos dos demais correligionários de partidos.

A escolha deste recorte para nossa discussão, justifica-se por dois motivos. Sendo o primeiro devido o pleito de 1982 ter sido de grande importância para os rondonienses, pois foi nesta eleição onde o estado recém-criado ${ }^{1}$, elegeu a sua primeira bancada federal no Congresso Nacional e escolheu os seus primeiros legisladores estaduais ${ }^{2}$.

Cabe destacarmos a relevância do processo eleitoral de 1982 a transição política nacional, tendo em vista constitui-se uma das etapas da abertura política brasileira da ditadura ao regime democrático ${ }^{3}$.

A segunda razão da delimitação temporal, liga-se diretamente a grande presença de evangélicos no estado de Rondônia neste período. Vale ressaltar, que no início dos anos 1990, o sociólogo Paul Freston, ao realizar mapeamento dos evangélicos no Brasil recorrendo ao censo de 1980, já trazia informações sobre o avanço dos evangélicos no Estado de Rondônia, relacionava tal avanço aos projetos de colonização,

O Estado de Rondônia é o mais protestante do Brasil. Em 1970 havia apenas 5\% de protestantes lá; agora, deve estar com bem mais de $20 \%$. Na zona rural, em 1980 , um em cada cinco pessoas $(21,00 \%)$ era protestante, um em cada oito $(12,06 \%)$ era pentecostal. Rondônia é o único de superposição dos dois tipos de protestantismo popular brasileiro: o pentecostalismo e o luteranismo. Com as transformações

\footnotetext{
1 Através da Lei Complementar $\mathrm{N}^{\circ} 41$ de 22 de dezembro de 1981 o Território de Rondônia é elevado a condição de Estado, informação obtida http://www.planalto.gov.br/ccivil 03/LEIS/LCP/Lcp41.htm acesso em 08 de fevereiro de 2019.

${ }^{2}$ MATIAS, 1998, P.150

${ }^{3}$ NICOLAU, 2012
} 
fundiárias no Sul, deslocou-se uma massa de agricultores luteranos para a fronteira do noroeste ${ }^{4}$.

Desta forma, percebe-se no estudo de Paul Freston existir no Estado de Rondônia uma grande quantidade de adeptos à religião evangélica; e que o fator determinante para que Rondônia se destacasse nacionalmente nos índices do IBGE como o Estado com maior quantidade de protestantes do Brasil nos anos 1980 foi a política de colonização do governo ditatorial. Freston frisa ainda que neste período a Assembleia de Deus foi "a única grande igreja a implantar-se e irradiar-se fora do eixo Rio-São Paulo"5, conseguindo expandir-se nacionalmente.

Entretanto de antemão cabe acentuar não termos encontrado projeto político oriundo dos evangélicos, melhor dizendo, da igreja Assembleia de Deus. A participação dos fiéis na campanha ocorre de modo semelhante em todo o Brasil. Ou seja, de maneira tímida, e com a instituição mantendo-se oficialmente distante da campanha.

Recorremos a variadas fontes na confecção do texto, entre elas optou-se pelas fontes orais com entrevistas realizadas com Berenice Silva (esposa do citado deputado pedessista), Luiz Lenzi, Rubens Silva e Sadraque Muniz. Tendo elaborado roteiro dirigido e desenvolvendo as demais etapas metodológicas de transcrição, textualização, transcrição e registro em cartório ${ }^{6}$.

Igualmente recorremos a dois jornais de grande circulação no estado, mediante as posições de ambos, o jornal Alto Madeira tinha proximidade com políticos do PDS no referido ano eleitoral atuou na propaganda de candidatos governista ${ }^{7}$; o periódico $O$ Guaporé em 1982 era de propriedade do secretário estadual do PMDB, Múcio Atayde, sob a administração deste o periódico torna-se oposição ${ }^{8}$ e dedicou-se a divulgar as candidaturas dos postulantes oposicionistas ${ }^{9}$.

\footnotetext{
${ }^{4}$ FRESTON, Paul. Protestantes e Política No Brasil: Da Constituinte ao Impeachment. Tese (Doutorado). Universidade Estadual de Campinas. 1993. p.35.

${ }^{5}$ FRESTON, Paul. Protestantes e Política No Brasil: Da Constituinte ao Impeachment. Tese (Doutorado). Universidade Estadual de Campinas. 1993.p.35

${ }^{6}$ MEIHY, José Carlos Sebe Bom. Manual de História Oral. $5^{\circ}$ ed. São Paulo: Edições Loyola, 2005.

${ }^{7}$ DIAS, Vinicius. A Participação dos Candidatos Evangélicos a Deputados Estaduais na Eleição de 1982 no Estado de Rondônia. Monografia (Departamento de História) - Universidade Federal de Rondônia, Porto Velho 2017.

${ }^{8}$ FORINI, Paola. Jorge Teixeira, Primeiro Governador do Estado de Rondônia: Imprensa e Cordialidade (1979-1982). (Dissertação) Mestrado em História e Estudos Culturais da Fundação Universidade Federal de Rondônia, Porto Velho 2014.

${ }^{9}$ DIAS, Vinicius. A Participação dos Candidatos Evangélicos a Deputados Estaduais na Eleição de 1982 no Estado de Rondônia. Monografia (Departamento de História) - Universidade Federal de Rondônia, Porto Velho 2017. p. 18
} 


\section{Breve Biografia de Amizael Silva e Sadraque Muniz}

Amizael Silva é natural de Bacabal cidade maranhense, em 1950 na infância acompanhado da família passou a viver no território rondoniense (na época era Território Federal do Guaporé), devido a atividade do seu pai que desempenhava funções na garimpagem e o atual município de Santa Luzia D’Oeste foi um dos locais onde morou ${ }^{10}$.

Mas residiu a maior parte da vida na cidade de Porto Velho, a formação do ensino básico se deu na tradicional escola da capital, Carmela Dutra. Formou-se me pedagogia pela Universidade Federal do Pará, desenvolvendo a atividade profissional na docência até após o termino da carreira política em 1990, passando a exerce as funções como professor na Universidade Federal de Rondônia ${ }^{11}$

Devido a amizade construída na época de estudante no ensino básico com os futuros proprietários do Alto Madeira, tinha uma coluna no periódico chamada Item Cultural, destinava a publicação de textos acerca das trajetórias de formação das cidades de Rondônia. Posteriormente publicou os livros Nos Rastros Dos Pioneiros (1984), Conhecer Rondônia (1999) oriundos da tentativa de reunir alguns fragmentos publicados nesta coluna.

Devido ao prestígio social como educador e escritor, angaria a cadeira de $n^{\circ} 40$, da Academia de Letras de Rondônia, à vista disso, integra-se junto a elite erudita rondoniense.

$\mathrm{Na}$ trajetória política começou pela Câmara Municipal de Porto Velho, sendo edil de 1976 a 1982, filiado na antiga ARENA. Tinha grande respaldo no partido, o PDS, e no pleito de 1982 tinha vaga garantida na disputa por uma das cadeiras da Assembleia Legislativa ${ }^{12}$

Já Sadraque Muniz é natural de Minas Gerias, porém vivera 15 anos no Paraná, trabalhando em selaria de calçados. Em fevereiro de 1974 junto com esposa e filhos migram para Rondônia, fixando-se na atual cidade de Ji-Paraná, a procura de terras distribuídas pelo governo federal, o qual recebera e ajuda na fundação do Sindicato dos Produtores Rurais, depois lidera a instituição ${ }^{13}$.

Foi ainda no Paraná que se filiou no PMDB, em Rondônia nos pleitos eleitorais de 1974 e 1978 trabalhou na campanha de deputado federal de Jerônimo Santana, o qual ele o considera como seu mestre político.

${ }^{10}$ SILVA, Berenice, 08/07/2017

${ }^{11}$ SILVA, Berenice, op.

${ }^{12}$ ALTO MADEIRA, 19/02/1982, PDS FARÁ PESQUISA PARA DEFENIR OS CANDIDATOS, n 13.958.

${ }^{13}$ MUNIZ, Sadraque, 21/03/2017 
Também tinha um programa de rádio, voltado ao segmento evangélico. Na campanha de 1982 justa a popularidade na região de domicilio e reconhecimento de potencial no partido, foi escolhido na composição chapa de candidatos a deputados estaduais.

Porém a decisão de concorrer na eleição de 1982 recebeu resistência dentro de sua comunidade religiosa: “O pastor Manuel Cassimiro (na época, o meu pastor), deseja ver eu seguindo o ministério de pastor, sendo contra a minha candidatura"14.

\section{Políticos Evangélicos}

Iniciamos o debate dialogando com as concepções teóricas do sociólogo Leonildo Campos e, fazendo alguns avanços temporais para sustentamos nossa hipótese onde os sujeitos estudados fugiram de rótulos de identificação de serem os candidatos dos evangélico, mas simplesmente de representantes do público em geral.

Os personagens estudados se encontram inseridos no termo definido pelo estudioso de “político evangélico", conforme caracterização abaixo:

Porém, a maioria desses políticos foi eleita em função do capital econômico ou simbólico acumulado por suas famílias ou por eles mesmo. Muitos deles eram protestantes de segunda ou terceira geração, filhos de famílias que se destacaram por serem fazendeiros ou os novos ricos do comércio, pessoas que podiam dar educação superior aos seus filhos. Cabe também ressaltar que não havia ainda estratégias corporativistas, fundamentadas em condições objetivas de que os evangélicos poderiam eleger seus representantes, embora já houvesse em alguns a aspirações políticas, fato ao qual João do Rio fez referência em um seu texto famoso ${ }^{15}$

Seguindo o conceito do sociólogo, podemos visualizar em Amizael Silva e em Sadraque Muniz a utilização de capital simbólico, um capital que eles já possuíam e que ambos reforçaram durante a campanha. Naquele momento o primeiro, possuía experiência política, ocupara cargos eletivos, e a identificação de sua candidatura com a representação dos educadores era um ponto a mais na busca de votos. Além disso, era figura destacada no meio evangélico, pois cresceu dentro da igreja, dedicando-se nas ações religiosas, e se não bastasse, o seu casamento também é importante no reforço da sua imagem pública como cidadão evangélico, haja visto, que contraíra matrimonio com a filha do então Presidente Geral da Igreja Assembleia de Deus. Portanto, ele e a sua família eram bastante conhecidos pela comunidade religiosa o que colocava a sua candidatura em evidência.

\footnotetext{
${ }^{14}$ MUNIZ, Sadraque, op

15 CAMPOS, Leonildo Silveira. Os "políticos de cristo" - uma análise do comportamento político de protestantes históricos e pentecostais no Brasil. In: XXVI ANPOCS, Caxambu, outubro de 2002. p. 3
} 
Quanto a Sadraque Muniz, possuía vivencia política anterior, onde se destacava por sua atuação como líder de sindicato e por sua atuação no PMDB, em atividades de campanhas eleitorais de seus mentores, José Viana e Jerônimo Santana. Estas experiências garantiram a definição da sua candidatura a deputado. No âmbito religioso, a identidade de filho de pastor o distinguia de outros crentes e foi uma marca importante da sua identidade social e pessoal (Sadraque permanece até hoje ao lado da família na igreja).

Em 1982, mesmo contrariando o chefe religioso da sua igreja, o Pr. Cassimiro, se inscreveu no pleito eleitoral, após o que obteve o seu apoio e o apoio dos evangélicos à sua candidatura. Durante a campanha, apresentando-se como opositor do governo ditatorial, conseguiu atrair de votos de católicos e umbandistas.

Durante a entrevista que foi realizada com Sadraque Muniz, ao indagar-lhe, pela segunda vez, sobre a procura de votos nas igrejas evangélicas, o ex-deputado disse que, na época, os evangélicos eram pouco expressivos em quantidade. A respeito do assunto ele disse: “em relação a campanhas nas igrejas, vale ressaltar que as igrejas evangélicas eram fracas, muito pequenas, tudo estava começando em Rondônia." 16 .

A afirmação de Sadraque Muniz, de que que as "igrejas eram fracas, muito pequenas, tudo estava começando", entra em contradição com outras informações sobre o avanço neopentecostal em Rondônia, pois segundo o historiador Josué Melo, durante a presidência do pastor Leonardo Severo Luz, entre 1953 a 1980, este promoveu a implantação da igreja em todo o Estado de Rondônia, tendo auxiliado diversas missões religiosas nos núcleos populacionais em formação na BR-364. É importante lembrar que coube a Pr. Leonardo Severo a estruturação da CEMADERON (Convenção dos Ministros da Assembleia de Deus de Rondônia), sendo o líder desta organização por vinte sete anos ${ }^{17}$

Analisando os dados do censo de 1980 e a PNDA de 1988, Freston mostra um crescimento geral de $8 \%$ dos evangélicos no Brasil. Mas ele ressalta: “O crescimento não é explicação suficiente para a entrada na política. Cada grupo reage às oportunidades de acordo com suas características internas" ${ }^{\prime 18}$. Portanto, o sociólogo sugeria que o aumento do grupo religioso não estava associado ao ingresso de evangélicos na política. Mas ressalvava

\footnotetext{
${ }^{16}$ MUNIZ, Sadraque, op.

MELO, Josué. Cadeias em chamas: A igreja Pentecostal na formação de Porto Velho - 1922 Monografia (Departamento de História) - Universidade Federal de Rondônia, Porto Velho 2013. p.55.

${ }^{18}$ FRESTON, Paul. Protestantes e Política No Brasil: Da Constituinte ao Impeachment. Tese (Doutorado). Universidade Estadual de Campinas. 1993.p.27
} 
que mesmo em 1982 “já havia um despertar político entre os pastores, mas nada que parecesse com o projeto eclesiástico de quatro anos depois"19.

Assim, na conjuntura das comunidades religiosas da época, se os candidatos estudados houvessem optado por um slogan de campanha na qual eles se autodenominassem candidatos da igreja (algo comum nos últimos pleitos eleitorais), ou decidissem montar nos templos comitês de campanha para alavancar as suas candidaturas este espaço de atuação eleitoreira dificilmente poderia existir. Neste sentido, comungando com Francisco Rolim, devemos entender a estrutura hierárquica das igrejas pentecostais ${ }^{20}$, no caso aqui examinado a Assembleia de Deus, que do alto da sua hierarquia eclesiástica estabelecia aos fiéis da sua membresia a ordem proibitiva: "fiquem distantes" e "a igreja não faz política".

Pouco tempo depois das eleições de 1982 observa-se que houve alteração na postura política adotada por esta igreja. A mudança aconteceu quando foi tomada a decisão de lançar e apoiar oficialmente os "candidatos da igreja". Mas esta não foi uma decisão aleatória ou isolada, houve uma ordem. A ordem veio do alto. A decisão foi tomada na Convenção Geral da Assembleia de Deus, acontecida em janeiro de1985 na cidade de Anápolis em Goiás, agrupando pastores e políticos como o governador Iris Rezende e o deputado federal José Fernandes. Ao debaterem o tema da nova Constituição, a elite da igreja defendeu o ingresso dos crentes na política ${ }^{21}$.

Mesmo assim, a entrada dos evangélicos na política ocorria aos poucos, ainda sobre a posição de neutralidade. No seu principal periódico, Mensageiro da Paz, a Assembleia de Deus anunciava um encontro que aconteceria no mês de fevereiro de 1985 entre líderes dessa igreja e o presidente eleito Tancredo Neves informava ainda que durante esse encontro seriam discutidos temas voltados para a economia, retaliações católicas aos evangélicos e exclusão das simbologias das religiões afro-brasileiras na moeda do Brasil ${ }^{22}$. É interessante notar o modo como a igreja criava pautas e passava a fazer exigências das suas demandas, chegando a cobrar posição do futuro chefe do executivo nacional.

\footnotetext{
${ }^{19}$ FRESTON, Paul. Protestantes e Política No Brasil: Da Constituinte ao Impeachment. Tese (Doutorado) Universidade Estadual de Campinas. 1993.p.209

${ }^{20}$ ROLIM, Francisco. Pentecostais no Brasil - uma interpretação sócio-religiosa. Petrópolis: Vozes, 1985.

${ }^{21}$ FRESTON, Paul. Protestantes e Política No Brasil: Da Constituinte ao Impeachment. Tese (Doutorado). Universidade Estadual de Campinas. 1993. p. 210

${ }^{22}$ FONSECA, André Dioney. Informação, política e fé: o jornal Mensageiro da Paz no contexto de redemocratização do Brasil (1980- 1990). Revista Brasileira de História. São Paulo, v. 34, n68, p.279-3022014. p.287-288.
} 
A largada dos evangélicos da Assembleia de Deus rumo à participação na política eleitoral aconteceu em abril do mesmo ano, na capital federal, durante uma reunião com representantes de cada federação da igreja, pois a instituição decidiu buscar protagonismo político, justificando-se da seguinte maneira:

\begin{abstract}
A nossa igreja tem suficiente potencial para colocar um representante em cada Estado no Parlamento... O compromisso da igreja, nesse caso, não pressupõe um envolvimento político partidário, pois a nossa segurança está em Deus, mas representa um esforço da igreja de manifestar sua benéfica influência nas mais altas esferas da vida pública ${ }^{23}$.
\end{abstract}

A partir daí podemos perceber a entrada dos evangélicos publicamente na política, com projetos em construção. A partir de então a instituição apresenta-se como mais uma das organizações civis que podem contribuir nos debates políticos. Mas é a partir de 1990 que os evangélicos estarão mais organizados para participar da política, ao passo em que as candidaturas se justificariam como frutos da escolha de Deus. Na concepção de Leonildo Campos, neste momento ocorre uma mudança nas características do "político evangélico" para dar lugar à fabricação dos "Políticos de Cristo"24.

No estado de Rondônia, no ano de 1986, segundo a Sra. Berenice Silva, a igreja declarou apoio a um candidato a deputado estadual do interior rondoniense. Porém, nesta mesma entrevista, embora sem se aprofundar neste assunto, a esposa de Amizael Silva, falou da força política em ascensão de lideranças da Assembleia de Deus do interior (estes hoje comandam a CEMADERON), por este motivo tais lideranças conseguiram impor a escolha do candidato ${ }^{25}$

Curiosamente, no panfleto da ALER- RO, se faz menção a um projeto de lei de autoria de Amizael garantindo à Associação dos Ministros Evangélicos Pentecostais do Estado de Rondônia (AMEPER) o reconhecimento de "Utilidade Pública" e este título, concedido às organizações sem fins lucrativos, o qualificava para receber verbas do governo estadual em nome da AMEPER ${ }^{26}$. Teria ele também deixado de prestar contas dos valores recebidos do governo em nome da AMEPER? Seria por isto que a igreja negara o apoio à sua candidatura? Os motivos pelos quais Amizael Silva foi preterido nas eleições do ano de 1986 não será discutido aqui, deverá ficar para um estudo posterior.

\footnotetext{
${ }^{23}$ Mensageiro da Paz, maio de 1985, p.1 Apud. Freston, 1993, p. 210

24 CAMPOS, Leonildo Silveira. Os "políticos de cristo" - uma análise do comportamento político de protestantes históricos e pentecostais no Brasil. In: XXVI ANPOCS, Caxambu, outubro de 2002. p.7

${ }^{25}$ SILVA, Berenice, op

${ }^{26}$ SILVA, Amizael, 1984, p.6
} 
Questionado sobre o posicionamento da Assembleia de Deus nos pleitos de 1986 e 1990, Sadraque Muniz disse desconhecer, mas atribuiu a sua derrota na disputa ao seu terceiro mandato como deputado à grande quantidade de candidatos evangélicos na disputa eleitoral ${ }^{27}$.

É interessante notar que na eleição de 1998 a Assembleia de Deus adotara a postura de fazer políticos do corpo de membros da igreja. Sadraque elucida este fato citando como exemplo a candidatura do filho, o ex-deputado federal Aguinaldo Muniz, "aí já foi uma bandeira evangélica, em 1998, na igreja começou a surgir o incentivo, teve uma comissão"28.

A partir daí formou-se uma comissão, da qual Sadraque Muniz (já como pastor) fez parte, que tinha por objetivo preparar os futuros "políticos de Cristo". Infelizmente não obtivemos detalhes sobre a função desta comissão. Questionado sobre a razão da mudança do posicionamento da igreja, Sadraque apresentou um motivo de alcance nacional, ao dizer:

Também existe um incentivo devido, estas bandeiras nacionais contra os evangélicos, de radicais ativistas gays, não os gays, não são os homossexuais, mas os ativistas dessa área, conheço muitos homossexuais, que até hoje convivo tranquilo e muito bem, nada contra nenhum homossexual ${ }^{29}$

No âmbito local, Sadraque Muniz recorreu às suas experiências pessoais bem como à de outros candidatos para explicar porque a Assembleia de Deus de Rondônia ingressou na disputa eleitoral. Disse ele:

Atualmente pode-se dizer numa agenda dos evangélicos, porque tem incentivo,
minha pessoa, Amizael e do Zé Viana, evangélicos que trabalhamos na política e
demos nossa participação, e quando a igreja trouxe a discussão do assunto de
candidatura de evangélico, teve pessoas que pode falar por experiência, na minha
época faltou isso, então nós lançamos uma semente ${ }^{30}$

As colocações de Sadraque Muniz corroboram com os estudos dos pesquisadores dessa temática mencionados nesta pesquisa. Ou seja, as bandeiras dos evangélicos a partir de 1990 encontram-se definidas. Prova disto é que existe uma preparação dos candidatos da igreja, diferentemente de 1982, onde os concorrentes recorram a outras estratégias e discursos. $\mathrm{Na}$ fala acima, é notória a tentativa de legitimar a memória das pessoas citadas como os percussores da largada dos evangélicos na política partidária em Rondônia.

Vale ressaltar, porém, que se o discurso eminentemente religioso fugia da retorica dos candidatos, é preciso frisar que a questão religiosa não foi negada. Convém, portanto, salientar que a motivação para realizar esta pesquisa era a busca de respostas para entender o

\footnotetext{
${ }^{27}$ MUNIZ, Sadraque, op.

${ }^{28}$ MUNIZ, Sadraque, op.

${ }^{29}$ MUNIZ, Sadraque, op.

${ }^{30}$ MUNIZ, Sadraque, op.
} 
elo entre política e religião no meio evangélico. No recorte temático que foi selecionado, desde o início sustentamos a hipótese de que um possível projeto político dos evangélicos encontrava-se ausente do horizonte dos candidatos nas eleições de 1982.

Desta forma, os púlpitos das igrejas não serviram de palanques eleitorais. Tampouco os pastores se apresentaram como mentores dos candidatos. Entretanto, o fato de os postulantes serem evangélicos contribuiu positivamente na obtenção de votos, já que em algumas ocasiões os templos tornaram-se ponto de encontro do candidato com amigos de infância e conhecidos da família, muitos deles companheiros de fé que o apoiaram politicamente. Dito de outro modo: os encontros do candidato com os seus potenciais eleitores ocorriam nas igrejas.

Se pensarmos propriamente em religião e política estas apresentam-se distantes. Porém, ao levar em consideração estes e outros aspectos percebemos proximidades entre ambas. E não estamos aludindo apenas às religiões evangélicas. Estamos nos referindo ao conjunto, ou seja, outras religiões como a católica e a umbanda, manifestaram-se politicamente nessas eleições. Exemplo disto é a declaração de um pai de santo, ao afirmar garantir votos de seu terreiro a um evangélico. Isto mostra preocupação dessa vertente religiosa e força nas questões políticas.

Estes exemplos elucidam bem, as lições de Maria Lúcia Montes, ao apontar o papel das religiões nas fronteiras do público e privado no Brasil,

\section{Entretanto, enquanto se estilhaçam as instituições, "longe das igrejas, perto da magia", é a importância do sagrado que assim se reafirma, demostrando que a religião na sociedade brasileira ainda é um elemento essencial na demarcação de fronteiras entre a esfera pública e a vida privada, num mundo que lentamente volta a reencantar-se ${ }^{31}$.}

Nesta perspectiva, a antropóloga chama a atenção do poder desta instituição social, sempre se reinventando e se adaptando às transformações, pois aproxima-se a virada do novo século/milênio, e, durante esse período ocorrem mudanças na lógica de pensar as funções do Estado. Entretanto, a religião mantém força nas mentalidades dos cidadãos.

Ainda considerado a posição da Assembleia de Deus sobre a relação religião e política e o perfil dos dois religiosos evangélicos que se lançaram na política partidária fica ainda nítido perceber que os candidatos seguiram, sim, as ordens da igreja. Mas de maneira não ostensiva. Ou seja, mantiveram-se fiéis às suas diretrizes, mas afastando-se da ideia de candidato da

${ }^{31}$ MONTES, Maria Lucia. As figuras do sagrado: entre o público e o privado IN: História da Vida privada no Brasil: Contraste da intimidade contemporânea, Vol. IV. Org. Shwarcz, Lilia Moritz. São Paulo: Companhia das Letras, 1998. p. 170 
instituição, pois as circunstâncias o exigiam. Quando a Assembleia de Deus abraça a causa da política eleitoreira, Amizael Silva esperava ser o representante escolhido e Sadraque Muniz liderava a formação dos futuros "candidatos de Cristo". Ao fim do processo, Amizael Silva encontrou resistência à sua candidatura, sendo derrotado e Sadraque Muniz obteve sucesso com a vitória do filho, eleito para o cargo de deputado federal.

Ao consultarmos a documentação sobre o tema da pesquisa fizemos um avanço temporal nos levou a observar algumas situações do comportamento eleitoral do ano de 1986 e da década de 1990. Os fatos que foram observados neste período serviram para demostrar, mais uma vez, que o comportamento dos candidatos evangélicos aconteceu de acordo a ética religiosa que orientava a conduta dos fiéis envolvidos na política à época. Ou seja, o postulante crente deveria apresentar-se para todos, porém jamais deixar de professar a opção religiosa.

\subsection{A disputa eleitoral de 1982 fora do contexto evangélico}

Até aqui insistimos em afirmar a ausência da participação de instituições religiosas na disputa pela conquista do poder político por candidatos evangélicos. Porém, no contexto desta eleição existia outra disputa em jogo: o duelo travado entre o grupo político liderado pelo governador Jorge Teixeira (PSD) e o da frente oposicionista comandada por Jeronimo Santana (PMDB).

Discorrer acerca de consultas eleitorais e compreender tais dinâmicas se torna importante no trabalho historiográfico como já dissera René Rémond, o comportamento eleitoral afeta as relações de forças de grupos políticos e a estabilidade das instituições ${ }^{32}$.

Ao se referir à França pós revolucionários René Rémond destaca a importância de se entender o fenômeno eleitoral, pois este tem contribuído para diversos estudos onde tais pesquisas proporcionaram interpretações sobre a composição dos governos e das fases republicanas constituídas. Para o historiador, pesquisas voltadas ao campo da política, proporciona entender caraterísticas de uma sociedade. Neste sentido, é importante destacar que "uma eleição é também um indicador do espírito público, um revelador da opinião pública e de seus movimentos"33.

\footnotetext{
32 RÉMOND, René. As Eleições IN: Por Uma história política. Org. RÉMOND, René. Rio de Janeiro: Editora FGV, 2003. p. 37-39.

${ }^{33}$ RÉMOND, René. As Eleições IN: Por Uma história política. Org. RÉMOND, René. Rio de Janeiro: Editora FGV, 2003. p.40.
} 
Em Rondônia existem carências de material de pesquisa ao se tratar de estudos eleitorais e das disputas de poder entre os líderes das bancadas oposicionista e governista, Jerônimo Santana e Jorge Teixeira, no entanto, podemos tirarmos algumas lições sobre as disputas e correlação de forças dos grupos de interesses, acompanhado o comportamento dos sujeitos deste estudo, pois estes representam uma parcela dos dois grupos antagônicos na disputa pelo controle político rondoniense.

O pleito de 1982 demarcava nacionalmente uma etapa do processo de abertura democrática, onde o governo ditatorial conduzira a transição, embora sabe-se da importância da luta armada e da mobilização de rua "Diretas Já"34.

No âmbito estadual, a dinâmica assemelha-se. O resultado da eleição iria definir qual grupo ditaria as regras e imporia a agenda ao novo Estado. Assim, visualiza-se organizações partidárias autodeclarando-se como oposição e governo. Vale frisar que localmente teremos uma instituição nova, a Assembleia Legislativa. Obter maioria nesta casa mostraria a forma de relação institucional entre os poderes executivo e legislativo. Quem tivesse mais cadeiras indicaria os futuros membros do colégio eleitoral na escolha do próximo presidente do Brasil.

A campanha dividia-se entre os defensores e críticos do governo. Nesse contexto, a oposição recorreu às falhas do Estado procurando culpar os governantes pelos erros econômicos e mazelas sociais, e denunciando os governistas de se apropriarem da máquina pública para fins eleitorais. Como ilustração, tomemos estas declarações de Sadraque Muniz,

1. O MDB na época não fez nenhum prefeito, pois Jorge Teixeira não permitiu, ele usava os órgãos e os carros públicos para fazer campanha abertamente, transportando candidatos e pedindo votos, até com o INCRA, isto é história. (MUNIZ, Sadraque. Ji-Paraná, 21/03/2017)

2. Sobre a justiça eleitoral aqui, teve um concurso para juiz, e a legislação da época discorria o seguinte: o juiz no estágio probatório, era proibido de presidir um pleito eleitoral. Então Jorge Teixeira reuniu os juízes, segundo informações de bastidores, e nesta reunião teria afirmado que na comarca onde os candidatos deles perdessem, o juiz estaria reprovado. O Juiz de Jaru na época teve que dá seu jeito, porque o vencedor foi o prefeito do PMDB, e no caso do Tomás Correia (candidato a deputado estadual), e teve influência, lutou e trabalhou, mas não teve recurso e sucesso, foi eleito mesmo o Baratela. A coisa não foi aberta, mas ostensiva, o pessoal dos órgãos públicos tudo empenhado na campanha da Arena $^{35}$

Vejamos a última estrofe da primeira fala. O candidato destaca as acusações de fraudes e abusos de poder, pois "isto é história". Os exemplos que foram apresentados por Sadraque Muniz, são idênticos aos que eram empregados pelos peemedebista para obter ganhos políticos.

\footnotetext{
${ }^{34}$ FICO, Carlos. História do Brasil Contemporâneo. São Paulo, Editora Contexto, 2015. p. 103-104.
}

${ }^{35}$ MUNIZ, Sadraque, op. 
Outro exemplo: O colega de chapa de Sadraque Muniz, Tomás Correia, chegou a entrar com ação na justiça eleitoral da cidade de Jaru, alegando acontecer naquele município a utilização de carros oficiais em prol dos candidatos pedessistas ${ }^{36}$

Portanto, a estratégia de denunciar os usos da máquina pública em prol dos candidatos do PDS fica nítida nesta petição de Tomás Correia. Na oportunidade, em entrevista concedida ao periódico O Guaporé, o advogado previa vitória do PMDB no interior do Estado. Porém, na cidade do citado postulante ela não ocorreu, conforme mencionado por Sadraque Muniz, porque houve fraudes na apuração dos votos.

Além disso outras denúncias foram feitas, inclusive no plenário da Câmara dos Deputados, entre estas, Jerõnimo Santana fez a acusação de veículos de comunicação estarem recebendo recursos do governo para fazerem propaganda para os candidatos do PDS, com exceção do jornal O Guaporé. Dizia-se que a TV Rondônia teria celebrado contrato de 60 milhões de cruzeiros com o PDS. Acordo duvidoso, segundo Jerônimo Santana ${ }^{37}$

$\mathrm{Na}$ reta final da campanha, os pemedebistas encaminharam oficio ao TRE-RO solicitando forças federais para atuarem no dia da votação. Temia-se fraudes nas linhas de colonização, principalmente em vicinais pertencentes a Ariquemes, Ji-Paraná, Jaru, Pimenta Bueno, Cacoal e nos distritos de Santa Luzia e Rolim de Moura ${ }^{38}$. Sobre esta denúncia devemos mencionar uma declaração do Governador Jorge Teixeira publicada pelo jornal Alto Madeira que oferece evidências de possível estratégia do governo nesta direção. Ou seja, o jornal informava que o governador utilizava a máquina do Estado para implantar urnas e para obter votos coercitivamente. O Alto Madeira, ao narrar a intenção do TRE de colocar urnas nas vicinais, alertava os eleitores

\footnotetext{
Colocarei urnas em todas as linhas dos projetos, porque assim saberei quem votou contra o nosso partido e tomarei as devidas providencias... pretendo continuar levando benefícios a todos os que escolheram Rondônia para viver. Mas vou beneficiar muito mais aqueles que estão do lado do governo, que os aos que estão do outro lado. Isso é ponto passivo ${ }^{39}$
}

Tendo em vista o propósito de entender a conjuntura eleitoral deixaremos de lado os embates entre esses oponentes e retomaremos a nossa discussão sobre as eleições de 1982. Assim, a declaração do governador e a reprodução da mesma no poderoso órgão de impressa

\footnotetext{
${ }^{36}$ O GUAPORÉ, TOMÁS CORREIA ENTRA COM PETIÇÃO CONTRA CARROS OFICIAIS NA POLÍTICA, p. $3,15 / 08 / 1982$.

${ }^{37}$ O GUAPORÉ, Jerônimo denuncia rádio e TV na campanha eleitoral, 03/09/1982, p.3.

${ }^{38}$ O GUAPORÉ, PMDB SOLICITA FORÇA FEDERAL PARA ELEIÇÕES, 11/11/1982, p. 3.

${ }^{39}$ ALTO MADEIRA, TRE QUER FACILITAR ACESSO ÀS URNAS, 14/08/1982, p.3.
} 
acorda com as manobras do governo na eleição para atender aos seus objetivos, mesmo se fosse necessário recorrer ao ato de por medo nos agricultores mediante intimidação de abandoná-los se contrariassem as ordens do coronel. O registro da fala do governador elucida que quando a oposição falava que estava ocorrendo abusos de poder por parte do governo, estes abusos faziam parte da realidade do período. Deste modo, os atos de retaliação do governo ditatorial aos opositores são primeiramente apresentados em forma de discurso que é tornado em prática repressiva.

Ao discorrer sobre essas eleições o sr. Luiz Lenzi também comentou sobre fraudes. Ele trouxe à memória o caso dos senadores eleitos, afirmando que o resultado que concedeu ao PDS as três vagas ao senado foi acertado em encontro secreto no Palácio Getúlio Vargas ${ }^{40}$

Sadraque Muniz menciona que outra arma retórica usada pelos opositores do governo era o alto custo de vida. Nos capítulos anteriores trouxemos exemplos do peso deste tema no contexto da campanha mostrando que o mesmo preocupava os situacionistas. O jornalista Ciro Arruda ao tratar dos pontos positivos e negativos do PDS e do PMDB dizia que a inflação era a maior responsável pela atração de votos da oposição,

[...] Além disso tudo, conta o partido oposicionista com o maior cabo eleitoral - O Alto Custo De Vida que, semana a semana, mês a mês diminui o poder aquisitivo dos menos favorecidos, sem que apareça autoridades capazes de porém freios aos poderosos, gananciosos e desumanos comerciantes sempre insatisfeitos com os que tomam do consumidor ${ }^{41}$

A inflação em alta gera na sociedade insatisfação. A maior parte da população sente o seu impacto. Por isso, a exploração do assunto pela oposição atraia parcelas do público eleitor. Dada a relevância da questão, e sabendo desta falha, o tema custaria caro aos governistas no dia do pleito.

O jornalista alerta os pedessistas acerca da inflação. Ele procura jogar a culpa disto nos empresários, classificando-os de interesseiros e acusando-os de estarem sempre buscando lucros para si. Após fazer tais acusações, conclui que a única parcela de responsabilidade de culpa do governo consiste em não tomar medidas contra esta situação na forma de uma intervenção do Estado no controle dos preços dos produtos em geral. Algo que acontecia, pois, o descontrole dos preços acompanha a fase das crises do petróleo de 1973 e 1979. Vale lembrar que durante este período "o governo tentou controlar as importações, mas o comércio

\footnotetext{
${ }^{40}$ LENZI, José Luiz, 13/06/2017.

${ }^{41}$ ALTO MADEIRA, A COPA PASSADA E O PLEITO FUTURO, 26-27/09/1982, p.7.
} 
mundial desacelerou depois de 1978 e as reservas brasileiras, que já vinham caindo desde 1974, caíram ainda mais. $" 42$.

Ao analisamos o perfil da equipe econômica de João Figueiredo para compreendermos melhor as críticas feitas ao governo pelo jornalista do Alto Madeira. Contatamos que, que os empresários agressivos ao qual o jornalista se refere estavam representados dentro do governo, pois

[...] o congresso nacional foi privado de sua prerrogativa de aprovar o orçamento da União, nos anos 1970 e 1980, o Conselho Monetário Nacional, na pratica, o substituiu. Representantes dos bancos, das industrias, os grandes comerciantes, exportadores e fazendeiros decidiam quanto seria emprestado a eles próprios, quais subsídios beneficiariam a ele mesmos, quanto de inserção fiscal o favoreceria ${ }^{43}$

Ou seja, os burocratas empresários e políticos militares, todos colhiam a adoção de uma política austera e fracassada da era do "milagre econômico".

Durante o processo eleitoral de 1982 o jornal o Guaporé também dedicou manchete à inflação e quem abordava o tema era ninguém menos que o proprietário do periódico. Ao discutir sobre o assunto o periódico promove o candidato Mucio Atayde, pois como homem de negócios o empresário tinha capital simbólico para tratar sobre o assunto, pois era um notável cidadão que discorria a respeito da questão ${ }^{44}$

Então, os fatos citados anteriormente, seja a denúncia feita por Tomás Correia; ou as acusações de Jerônimo Santana aos deputados federais de que o Governo de Rondônia repassava verbas aos órgãos de imprensa; e também as críticas de Múcio Athayde ao alto custo de vida, mostram como os candidatos pemedebistas, inclusive Sadraque Muniz, recorriam a estes temas na campanha.

Se a oposição se concentrou nas denúncias de fraudes e de incompetência na política administrativa do Estado. Do lado governista, o esforço da campanha girou na defesa do governo de Jorge Teixeira, com o PDS apresentando Rondônia como exceção das dificuldades econômicas que o país atravessava. Neste sentido, o que se ressaltava nos discursos era que aqui o desenvolvimento estava em pleno vapor, apesar de reconhecimento da alta dos preços. Este problema, no entanto, era abordado como uma questão que em breve o governador e o presidente iriam resolver, bastava a população votar nos candidatos do PDS.

\footnotetext{
${ }^{42}$ FICO, Carlos. História do Brasil Contemporâneo. São Paulo, Editora Contexto, 2015. p.109-110

${ }^{43}$ FICO, Carlos. História do Brasil Contemporâneo. São Paulo, Editora Contexto, 2015. p.111.

${ }^{44}$ O GUAPORÉ, O CUSTO DE VIDA CONTINUA A SUA ARRANCADA, 22/10/1982, p.1.
} 
Ocultado da opinião pública até 1985 os atritos entre Amizael Silva e o governador Jorge Teixeira, inclusive o apelido de "crente encrenqueiro" dado pelo governador. Na campanha de 1982 Amizael Silva seguiu a estratégia publicitaria de mostrar que era um candidato do grupo do "Teixeirão", pois isto the rendeu visibilidade haja vista que o governante tinha carisma junto ao eleitorado.

Michael Pollack, ao discutir sobre os não ditos, enquadra os silêncios sendo uma memória subterrânea, alguns fataos dos acontecimentos, na maioria das vezes fica restrito ao grupo familiar, por diversos motivos ${ }^{45}$

Na campanha de 1982 Amizael Silva seguiu a estratégia publicitaria de mostrar que era um candidato do grupo do "Teixeirão", pois isto lhe rendeu visibilidade haja vista que o governante tinha carisma junto ao eleitorado. Também se dava destaque ao fato de que ele tinha outros compromissos junto a outras alas do PDS, partido que ele ajudou a fundar e de cuja agremiação era um defensor intransigente.

Mediante a atividade profissional, adotou o slogan de campanha "ei de vencer, mesmo sendo professor", redigiu uma carta aos professores, esta reproduzida nos dias 7, 8, 9 e 10 de agosto no Alto Madeira

Carta Aos Professores

Porto Velho, agosto de 1982

Colega professor (a).

Naturalmente você está surpreso (a) ao ler esta carta, e terá, "a priori”, pensado que é em virtude das eleições próxima.

Acertou!

Há um ditado popular que expressa os motivos que me levaram a escrever-lhe "Quem têm sede vai ao pote..."

Você, talvez, nunca me tenha procurado, naturalmente porque não houve necessidades, de sua parte.

Quanto a mim, sou CANDIDATO A DEPUTADO ESTADUAL E NECESSITO DE SUA PROCURAÇÃO, que é o voto.

Você tem acompanhado as notícias veiculadas em nossa impressa local, sobre os problemas do professor?

Então saberá de nossa atuação, de nossa luta e das vitórias, modéstias à parte, principalmente sobre salária. sobre vantagens e aspectos legais (quatro semanas e meia, por exemplo).

Você também deverá ter observado que as classes sociais se organizam e apontam candidatos de sua profissão ou formação porque sabem que a Constituinte responsável pela elaboração da constituição do nosso Estado exigirá, além de conhecimentos, vivência profissional.

E você? ...

Sou pós-Graduado em Pedagogia e tenho vivência no magistério - meu Deus! há mais de duas décadas, vivendo agruras de professor leigo, de monitor de ensino, de $1^{\circ}, 2^{\circ}$ e $3^{\circ}$ graus.

${ }^{45}$ POLLAK, Michael. Memória, esquecimento, silencio. Estudos Históricos. Rio de Janeiro: CPDOC-FVG, v.2. n.3, 1989. p.8 
O que estou tentando dizer-lhe é que sou o elemento indicado para representá-lo (a) na constituinte, porque VIVÊNCIO o magistério seja como professor, secretário ou diretor de estabelecimento de ensino.

Ainda mais: sou de uma família de professores -eu, esposa, sogra, cunhados, filhos e sobrinhos pertencemos à classe.

Portanto, escolha o que é melhor para você: um colega de profissão, a seu serviço, na Assembleia Constituinte deste Estado que você ajudou a fazer.

Cordiais Saudações,

Professor Amizael Gomes da Silva ${ }^{46}$

Observe-se como o candidato, enfatizou o cargo ao qual disputava, e ponderou que devido vivenciar a realidade dos demais colegas do magistério, se apresentava como a melhor opção para representar a categoria dos professores no parlamento estadual. Referendava a sua capacidade acrescentando que era membro de uma família de educadores, logo, conhecia bem os interesses desses. Portanto, tendo em vista a Constituição a ser elaborada, a classe necessitaria de um representante, conhecedor e empenhado em defender os seus interesses na Carta Magna.

O enunciado do jornal, ao chamar os leitores para lerem a matéria, permite entender ter o manifesto sido distribuído para os diversos profissionais da educação, em especial os professores. Entende-se também que o periódico reproduziria o panfleto com objetivo de reafirmar o discurso do candidato, pois a escolha da página 4 , e reedição da notícia em quatro dias consecutivos, acontecia intencionalmente.

A imprensa desempenha papel importante nos momentos políticos chaves, selecionando as publicações com intenções de convencimento subjetivamente a alguma causa ${ }^{47}$, os seus leitores ao entenderem o posicionamento de Amizael Silva perceberiam como a legitima representação da categoria.

Conseguir um lugar reservado na impressa foi algo positivo na cristalização da imagem da candidatura de Amizael Silva, pois no meio dos professores havia adversários políticos, entre eles o presidente da Associação Rondoniense dos Professores, o docente Mário Jorge ${ }^{48}$, que foi aluno do candidato. Rubens Silva ressalta: “Comungavam de muitos assuntos, mas era natural a disputa, e o fato de ele ser do PDS",49.

\footnotetext{
${ }^{46}$ ALTO MADEIRA, CARTA AOS PROFESSORES, 07/08/1982, p.4

47 CAPELATO, Maria Helena Rolim. A Imprensa Como Fonte e Objeto De Estudo Para o Historiador. IN: História das Américas: fontes e abordagens historiográficas. Orgs: VILLAÇA, Mariana \& PRADO, Maria Ligia Coelho. Editora Humanitas, São Paulo, 2015. p. 126 -130.

${ }^{48}$ Fora agendado entrevista com o professor Mario Jorge, mas no dia marcado, o mesmo não pode ceder sua colaboração por questões pessoais.

${ }^{49}$ SILVA, Rubens, 12/06/2017
} 
Este trecho de Rubens Silva, contribui para trazer episódios, os quais não se encontram nos documentos escritos, o fato de divergências entre dois professores bastantes conhecidos na categoria, tendo em vista a questão partidária, pois como sindicalista e com viés a esquerda, Mário Jorge distanciou-se do ex-professor, devido Amizael Silva pertencer ao partido da ditadura.

Dada a sua postura, ele recebia espaço no jornal Alto Madeira. Em diversas páginas deste periódico a menção de seu nome é clara: elogiando méritos, comparando-o aos outros candidatos. Importante frisar o bom trânsito de Amizael Silva nessa empresa de comunicação acontecia graças à amizade que ele mantinha com os proprietários e com os demais jornalistas do periódico.

Durante a leitura dos periódicos Alto Madeira e O Guaporé, em nenhum exemplar foi encontrada a associação de Amizael Silva ou Sadraque Muniz aos evangélicos.

Quanto ao apoio dos evangélicos a candidatura de Amizael Silva, a companheira disse o seguinte,

Ele não gostava de pedir votos nos cultos, mas era assim "vamos dar força para trazer um cantor, pregador" então ele tinha esse compromisso, trazia pastor, pregador, cantor e eles pediam votos por Amizael, não era exatamente voto, mas vamos ajudar, não era como hoje em dia, porém discreto o pedido do voto ${ }^{50}$

Mediante a fala acima, observa-se que o candidato indiretamente contou com a contribuição de fies da igreja, à sua candidatura devido a ações anteriores, bem como por causa do seu envolvimento no meio do segmento religioso. Isto configura o uso deste espaço, sim, na procura por votos, embora do ponto de vista oficial a instituição e o membro concorrente a pleito eleitoral passaram a ideia de haver neutralidade da igreja.

Importante esclarecer que uma grande parcela de amigos da capital e do interior, entre eles aqueles que compõe os grupos de agricultores, professores e taxistas, eram evangélicos ${ }^{51}$. Portanto, este grupo (de evangélicos) atuou na campanha de Amizael Silva. Ressaltamos que durante a campanha esse grupo era identificado por suas profissões, mas é evidente que eles apoiaram o candidato Amizael Silva, por causa do contato religioso. Não se deve, porém, negligenciar os interesses de classe dos referidos grupos, pois tal apoio poderia lhes garantir assistência nos seus anseios, melhor dito: os desafios sociais que eles enfrentavam eram

\footnotetext{
${ }^{50}$ SILVA, Berenice, op

${ }^{51}$ SILVA, Rubens, op
} 
semelhantes aos da população em geral e não eram apenas bandeiras de grupo, especificamente de evangélicos.

Em síntese, a análise da atuação de duas candidaturas às vagas de deputados estaduais nas eleições de 1982 por pessoas identificadas como evangélicas permitiu enxergar outros componentes do processo eleitoral: o papel da religião na nossa sociedade, questão que nos levou a dar os primeiros passos desta pesquisa com indagações acerca das relações entre a mesma e o poder. Necessariamente ela aparece na época distante, mas no decorrer desta investigação a percebemos com muita força. $\mathrm{O}$ simples fato dos candidatos terem respeitado as regras impostas pela hierarquia eclesiástica e de tê-las cumprindo no período devido a instituição religiosa o exigir desvincularam suas candidaturas da igreja.

Percebemos também o lugar da impressa na política eleitoreira. Neste sentido, os dois grandes jornais da época, Alto Madeira e O Guaporé declaravam em que espaço estavam atuando e quais os projetos de governo que defendiam por meio das notícias veiculadas.

Na modernidade o jornal se assemelha ao sagrado, como já dissera Lilia Schwarcz, porquanto o jornal tornou-se o Xamã da sociedade contemporânea, muitos leitores ao lerem as notícias deixam de apontar críticas ${ }^{52}$, desta forma as narrações dos periódicos encaminham os leitores na hora de decidir a preferência do voto. As propostas de campanha apresentadas no corpo dos textos são amostras das ações a serem implementadas pelos futuros legisladores.

\section{Considerações Finais}

Portanto, a eleição de 1982, vista de diversos ângulos, traz lições sobre diversos pontos. No caso dos evangélicos, não é possível enxergá-los à parte do contexto mais amplo no qual se inserem as suas atividades políticas e se desenvolvem as suas candidaturas. Isto significa que, no momento em que surgem como postulantes aos cargos eleitorais, os seguidores da fé religiosa defendem outros deuses, digo Jerônimo Santana e Jorge Teixeira.

Os candidatos apresentavam a mesma imagem e semelhança que tinham os deuses aos quais eles serviam pois afinal, homens e deuses estão na luta pelo poder político de Rondônia. Nesta luta eles vão apontando os erros humanos e fazendo acusações. São estes, pois, os responsáveis por tais ações. O sobrenatural não foi convocado a estar no meio deste embate.

\footnotetext{
${ }^{52}$ SCHWARCZ, Lilia Moritz. Retrato Em Branco e Negro: jornais, escravos e cidadãos em São Paulo no final do século XIX. São Paulo: Companhia das Letras, 1987. p. 294
} 
Diante do exposto, fica claro que a população deveria optar por dois projetos políticos. O projeto da oposição se comprometendo a solucionar os problemas da sociedade, como: a inflação, condução da abertura política e consolidação da instalação do novo Estado. Ao projeto dos governistas também caberia estes desafios, mas como defendiam ter acontecido um "desenvolvimento" em Rondônia, eles afirmavam que só dariam continuidade ao conjunto de ações que manteria esta situação. Portanto, tudo passaria pela escolha lógica do eleitorado ao optar pelo PMDB ou PDS, quer sob a condução do poderoso coronel ou do "simples deputado".

\section{Referências Bibliográficas}

CAMPOS, Leonildo Silveira. Os "políticos de cristo" - uma análise do comportamento político de protestantes históricos e pentecostais no Brasil. In: XXVI ANPOCS, Caxambu, outubro de 2002.

CAPELATO, Maria Helena Rolim. A Imprensa Como Fonte e Objeto De Estudo Para o Historiador. IN: História das Américas: fontes e abordagens historiográficas. Orgs: VILLAÇA, Mariana \& PRADO, Maria Ligia Coelho. Editora Humanitas, São Paulo, 2015.

DIAS, Vinicius. A Participação dos Candidatos Evangélicos a Deputados Estaduais na Eleição de 1982 no Estado de Rondônia. Monografia (Departamento de História) Universidade Federal de Rondônia, Porto Velho 2017.

FICO, Carlos. História do Brasil Contemporâneo. São Paulo, Editora Contexto, 2015.

FONSECA, André Dioney. Informação, política e fé: o jornal Mensageiro da Paz no contexto de redemocratização do Brasil (1980- 1990). Revista Brasileira de História. São Paulo, v. 34, n68, p.279-302- 2014.

FORINI, Paola. Jorge Teixeira, Primeiro Governador do Estado de Rondônia: Imprensa

e Cordialidade (1979-1982). (Dissertação) Mestrado em História e Estudos Culturais da Fundação Universidade Federal de Rondônia, Porto Velho 2014.

FRESTON, Paul. Protestantes e Política No Brasil: Da Constituinte ao Impeachment. Tese (Doutorado). Universidade Estadual de Campinas. 1993.

MATIAS, Francisco. Pioneiros Ocupação Humana e Trajetória Política de Rondônia. Porto Velho: Gráfica e Editora Maia Ltda., 1998. 
MEIHY, José Carlos Sebe Bom. Manual de História Oral. $5^{\circ}$ ed. São Paulo: Edições Loyola, 2005.

MELO, Josué. Cadeias em chamas: A igreja Pentecostal na formação de Porto Velho 1922 Monografia (Departamento de História) - Universidade Federal de Rondônia, Porto Velho 2013.

MONTES, Maria Lucia. As figuras do sagrado: entre o público e o privado IN: História da Vida privada no Brasil: Contraste da intimidade contemporânea, Vol. IV. Org. Shwarcz, Lilia Moritz. São Paulo: Companhia das Letras, 1998.

NICOLAU, Jairo. Eleições no Brasil: do Império aos dias atuais. Rio de Janeiro: Zahar, 2012.

POLLAK, Michael. Memória, esquecimento, silencio. Estudos Históricos. Rio de Janeiro: CPDOC-FVG, v.2. n.3, 1989.

RÉMOND, René. As Eleições IN: Por Uma história política. Org. RÉMOND, René. Rio de Janeiro: Editora FGV, 2003.

ROLIM, Francisco. Pentecostais no Brasil - uma interpretação sócio-religiosa. Petrópolis: Vozes, 1985.

SCHWARCZ, Lilia Moritz. Retrato Em Branco e Negro: jornais, escravos e cidadãos em São Paulo no final do século XIX. São Paulo: Companhia das Letras, 1987. 